Water and ammonia evaporation in a compost bedded pack dairy barn with under floor aeration

Bjerg, Bjarne Schmidt; Klaas, Ilka Christine

Published in:

ASABE / CSBE/ASABE Joint Meeting Presentation

Publication date:

2014

Document version

Early version, also known as pre-print

Citation for published version (APA):

Bjerg, B. S., \& Klaas, I. C. (2014). Water and ammonia evaporation in a compost bedded pack dairy barn with under floor aeration. In ASABE / CSBE/ASABE Joint Meeting Presentation [141899106] American Society of Agricultural and Biological Engineers. 


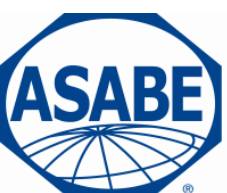

2950 Niles Road, St. Joseph, MI 49085-9659, USA 269.429.0300 fax 269.429.3852 hq@asabe.org www.asabe.org

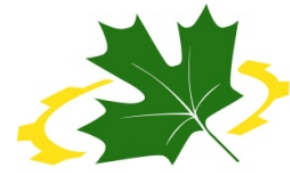

CSBE | SCGAB
An ASABE - CSBE/ASABE Joint Meeting Presentation

\title{
Water and ammonia evaporation in a compost bedded pack dairy barn with under floor aeration
}

\author{
Bjarne Bjerg and Ilka Klaas, University of Copenhagen, Denmark
}

\author{
Written for presentation at the \\ 2014 ASABE and CSBE/SCGAB Annual International Meeting \\ Sponsored by ASABE \\ Montreal, Quebec Canada \\ July $13-16,2014$
}

\begin{abstract}
.
The paper reports experiences from the first composted bedded pack (CBP) barn for 330 dairy cows in Denmark. The design of the barn differs from corresponding barns in the US by including an under floor aeration system to enhance water evaporation from the CBP. As bedding material were mainly used garden residuals, chopped roots and heathland vegetation.

The water evaporation during the investigated 313 days period amounted for $6.1 \mathrm{t}$ cow $^{-1}$ corresponding to $70 \%$ of the moisture included in the added manure and bedding material. Because of the relatively large simultaneous degeneration of organic dry matter $(\mathrm{dm})$ the water evaporation did not contribute to increased $\mathrm{dm}$ content in the CBP during the winter period. Conversely, the water evaporation in the summer period was so large that the $d m$ content in the CBP increased significantly even though no bedding material were added during a 193 days period.

Simple flux chamber measurement showed that the ammonia emission per area units was approximately $70 \%$ lower from the CBP areas than from the solid floor feeding place scraped each second hour. But due to the large ammonia releasing area of $10 \mathrm{~m}^{2}$ per cow the emission from a CPB barn seems to be approximately 30 $\%$ larger than from a free stall barn with solid floor alleys, which are scraped each second hour. However, the study indicated that the emission from the CPB barn is lower than from slatted floor free stall housing systems also frequently used in Denmark.
\end{abstract}

Keywords. Compost bedded pack, ammonia emission, water evaporation, under floor aeration system, flux chamber.

The authors are solely responsible for the content of this meeting presentation. The presentation does not necessarily reflect the official position of the American Society of Agricultural and Biological Engineers (ASABE), and its printing and distribution does not constitute an endorsement of views which may be expressed. Meeting presentations are not subject to the formal peer review process by ASABE editorial committees; therefore, they are not to be presented as refereed publications. Citation of this work should state that it is from an ASABE meeting paper. EXAMPLE: Author's Last Name, Initials. 2014. Title of Presentation. ASABE Paper No. ---. St. Joseph, Mich.: ASABE. For information about securing permission to reprint or reproduce a meeting presentation, please contact ASABE at rutter@asabe.org or 269-932-7004 (2950 Niles Road, St. Joseph, MI 49085-9659 USA). 


\section{Introduction}

The first larger composted bedded pack (CBP) dairy barn in Denmark was established in December 2012. The building is $140 \mathrm{~m}$ long and $40 \mathrm{~m}$ wide and was designed to house 330 organic Holstein Friesian milking cows. In Denmark dry sawdust and woodchips are valuable raw materials for green energy production and, therefore, it was planned to use cheaper bedding materials as garden residuals, chopped roots and heathland vegetation. In addition to the operation and design recommendations known from the US, the barn was equipped with an under floor aeration system, as is know from the Netherlands (Galama, 2011). The anticipated effect of the under floor aeration system was that it would enhance the water evaporation and reduce the required amount of bedding material.

The expected ammonia emission is an important criterion when a farmer in Denmark applies for permission to expand the herd. For naturally ventilated housing systems with liquid manure handling the required application has to be based on standard figures expressing the expected yearly ammonia emission per cow from the planned housing system. The used standard figures are determined in full scale on farm measurement using the expected carbon dioxide production from the animals as tracer gas to calculate the air change. The degradation of the bedding material in a CBP barn produces a significant amount of carbon dioxide that compromises the mentioned carbon dioxide measure method. Therefore, in this study we used a simple flux chamber method (Kousgaard, 2011) to investigate the ammonia emission from the CBP.

\section{Methods}

The study focuses on the CBP at one side of the feeding aisle from the day when the barn came into use (December $4^{\text {th }} 2012$ ) until most of the bedding was removed from the barn October $16^{\text {th }} 2013$. From May $11^{\text {th }}$ to the end of the period the cows were pasturing during the daytime. On average 165 milking cows were kept on the pack corresponding to $10 \mathrm{~m}^{2}$ per cow (exclusive a solid floor feeding place at the feed table). The added bedding materials were wood chips, chopped roots, heathland vegetation, green saw dust and dry sawdust. Recorded added and removed materials, and Danish standard figures for animal manure (Poulsen, 2012) were used to estimate a mass balance for the CBP. The pack was $55-70 \mathrm{~cm}$ deep and stirred daily with a rotor cultivator and occasionally in nearly full depth with heavy harrows.

The barn was designed with a $4 \mathrm{~m}$ wide solid floor feeding place between the feed table and a $12 \mathrm{~m}$ wide compost area, see Figure 1.

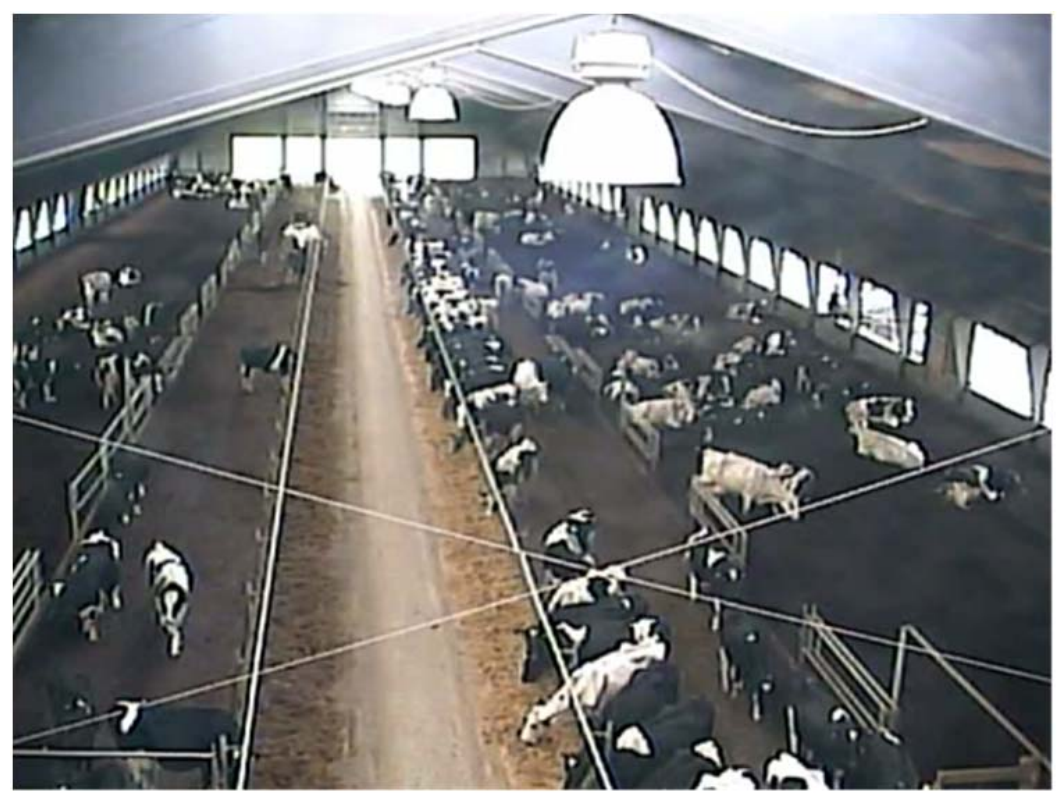

Figure 1. Overview picture of the investigated barn.

The feeding place had a $5 \%$ slope towards draining slots in the middle and an automatically scraper system was installed to remove the manure each second hour in order to fulfil the Danish requirements for low ammonia emission animal housing.

The under floor aeration system were design with a $600 \mathrm{~mm}$ main tube in the ground just outside each side of the building. The main tube supplied a $76 \mathrm{~mm}$ cross tube, for each $1125 \mathrm{~mm}$, embedded in the concrete floor beneath the compost bedded pack. Each cross tube supplied a $10 \mathrm{~mm}$ vertical tube per $600 \mathrm{~mm}$ which led the 

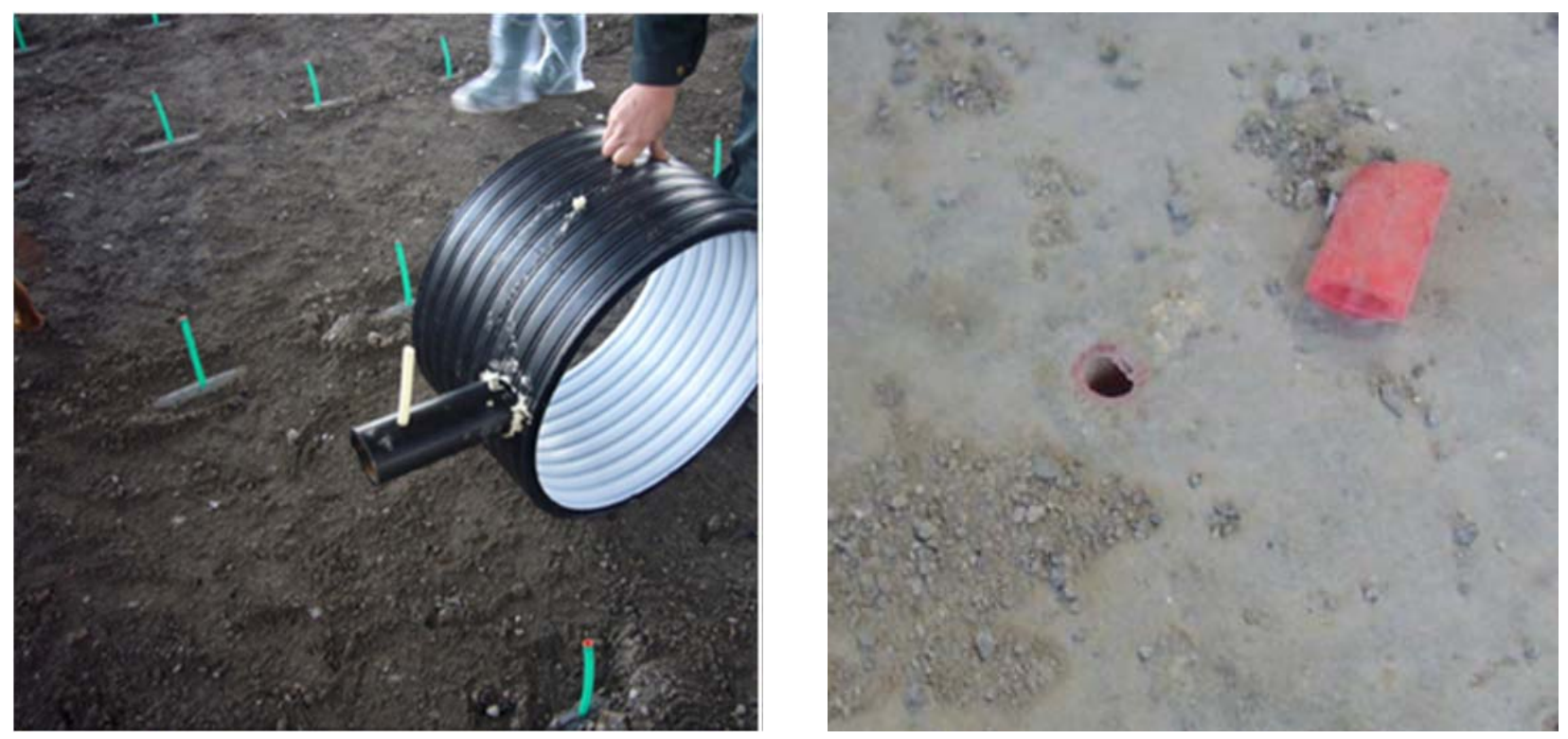

Figure 2. Tube system for aeration of the CBP. The picture to the left shows the vertical tubes before laying the concrete floor, and an illustration of the junctions of the three tube types. The picture to the right shows a vertical tube cut off at the height of the finished floor.

The installed fans have the capacity to deliver a flow of approximately $5 \mathrm{~m}^{3} \mathrm{~h}^{-1}$ through each of the 2480 holes in the floor of the investigated CBP at a back pressure of $900 \mathrm{~Pa}$. Measured back pressure was typically 950 $\mathrm{Pa}$ before and $850 \mathrm{~Pa}$ after the daily stirring of the CBP. The aeration system was operated 5 minutes each second hour during the winter period, and at daytime only during the summer period.

CBP dry matter (dm) content, ammonia emission, and CBP temperature were measured monthly during the winter period and approximately each second month during the summer period. In the winter period these measurements where based on recordings from 15 locations systematically distributed over the CBP. During the summer period the measurements were reduced to 5 locations and the $\mathrm{dm}$ content were determined from a mixed sample from these 5 locations.

Dm content in CBP samples were determined based on the relative mass loss by drying at $105{ }^{\circ} \mathrm{C}$ to mass equilibrium. During the winter period dm determination was based on individual samples from 0-45 $\mathrm{cm}$ depth taken with a post hole digger. At the end of the winter period the standard variations between the 15 individual samples was as low as $1 \% \mathrm{dm}$, and, therefore, it was decided to use a less work requiring sampling procedure in the subsequent summer period. Consequently, in the summer period the $\mathrm{dm}$ content determination was based on a pooled sample from 5 locations and taken from approximately $20 \mathrm{~cm}$ depth.

A $15 \mathrm{~cm}$ high simple plastic box was used as a primitive flux chamber to measure the ammonia emission from the CBP and from the scraped solid floor feeding place, see Figure 3. Inside the chamber a computer fan was installed to ensure an appropriate air mixing. A Kitigawa AP-20 sampling pump and ammonia detection tubes (105SD) were used for the ammonia concentration measurements. The detection limits of the used detection tubes was $0.5 \mathrm{ppm}$ and according to the instruction manual a sampling time of 1 minute was used. An earlier study (Kousgaard, 2011) showed that the ammonia increase in the chamber began to decline 1 minute after the chamber was placed on the surface. Therefore the ammonia measurements were conducted from 45 to 105 seconds after the chamber was placed on the floor. Because of declining air flow through the detection tubes during the 1 minute sampling period it was assumed that the measured ammonia concentration reflected the concentration 60 second after the chamber was placed on the surface. Generally the background concentration in the barn was below the detection limit of $0.5 \mathrm{ppm}$ and therefore no background concentration was taken in to account in the calculation of the ammonia emission. 


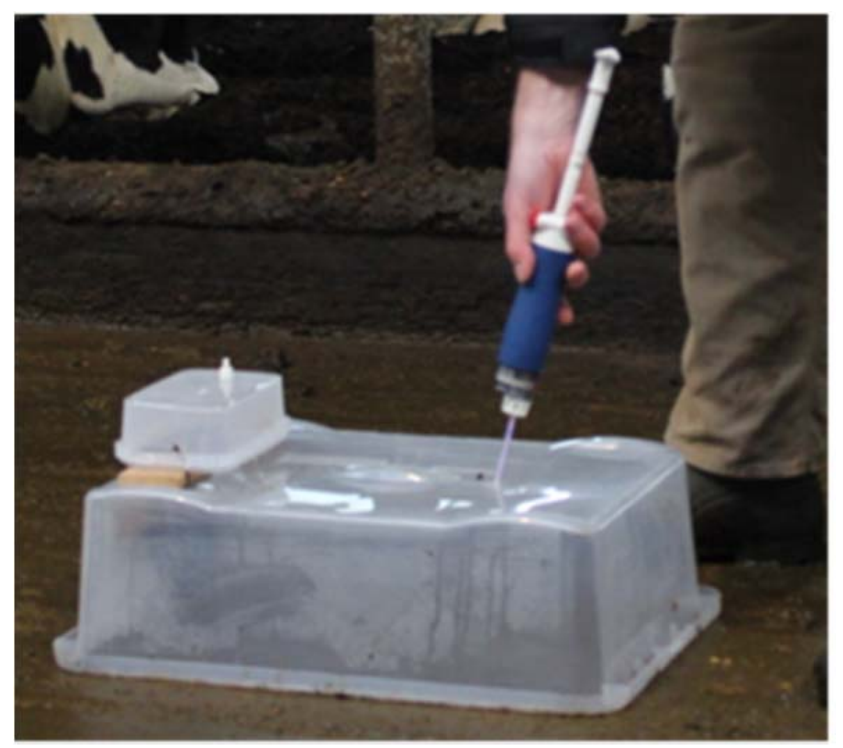

Figure 3. Simple flux chamber and a Kitigawa AP-20 sampling pump with 105SD detection tube for determination of ammonia emission.

Compost temperature was measured in approximately $30 \mathrm{~cm}$ depth using a Therma 1 thermometer and penetration probe from Electronic Temperature Instruments Ltd.

The compost bedding area was approximately $10 \mathrm{~m}^{2}$ per cow, and the amount of added bedding material appears from table 1 . Three quarters of the bedding material were added before the animals entered the barn and the last quarter was added during the winter period until April $5^{\text {th }}$.

Table 1: Added bedding materials.

\begin{tabular}{lcc}
\hline & Tonnes/cow & Dry matter, \% \\
\hline Wood chips including leaves, roots and garden residuals: & 3.4 & 43 \\
Sawdust and wood shavings & 0.5 & 83 \\
Heathland vegetation & 0.1 & 36 \\
\hline Totally: & 4.0 & 49 \\
\hline
\end{tabular}

Based on Danish norm figures for animal manure (Poulsen, 2012) it was estimated that each cow added 7.6 tonnes $(t)$ of manure $(12 \% \mathrm{dm})$ to the compost area during the investigated period. At the end of the period 3.2 $\mathrm{t}$ compost per cow $(40 \% \mathrm{dm})$ where removed from the barn, and it was estimated that $1.2 \mathrm{t}$ per cow remained in the barn at the end of the period.

Average dm content of added materials (\%) were calculated as:

$$
d m_{\text {added materials }}=\frac{\sum_{i}^{n} d m_{i} \bullet m_{i}}{\sum_{i}^{n} m_{i}}
$$

Where $d m$ is dry matter content (\%) and $m$ is the mass $(\mathrm{kg})$ of $\mathrm{n}$ different materials.

\section{Results and Discussion}

Table 2 summarizes the mass balance for the compost area during the investigated period. Four $t$ of bedding material $(49 \% \mathrm{dm})$ and $7.6 \mathrm{t}$ of manure $(12 \% \mathrm{dm})$ were added per cow. The total amount was $11.6 \mathrm{t}$ including $8.7 \mathrm{t}$ water. Together the mass of material removed from the barn or left in the barn at the end of the period was $4.4 \mathrm{t}$, corresponding to $38 \%$ of the added material. Consequently $62 \%$ of the mass was lost as water evaporation and as degradation of organic $\mathrm{dm}$ during the 313 days period. The water evaporation amounted for 
6.1 ton/cow (appears from table 2) corresponding to $70 \%$ of added moisture, whereas $38 \%$ only of the added dry matter was lost. The water evaporation was 4.5 times larger than the $\mathrm{dm}$ loss. Therefore, at the end of the period the bedding contained $41 \%$ dry matter even though the average dry matter content in the added material (bedding and manure) were as low as $25 \%$.

Table 2: Summery of estimated material balance for the compost area from December $4^{\text {th }} 2012$ to October $16^{\text {th }}$ 2013.

\begin{tabular}{lccc}
\hline & Totally & Dry matter & Water \\
\hline Added bedding (49 \% dm), t/cow: & 4.0 & 2.0 & 2.0 \\
Added manure (12\% dm), t/cow: & 7.6 & 0.9 & 6.7 \\
Removed material (40 \% dm), t/cow: & 3.2 & 1.3 & 1.9 \\
Left material (41 \% dm), t/cow: & 1.2 & 0.5 & 0.7 \\
\hline Evaporation (loss), t/cow: & 7.2 & 1.1 & 6.1 \\
\hline
\end{tabular}

Figure 4 compares measured $\mathrm{dm}$ content in the compost with calculated $\mathrm{dm}$ content in the added material (bedding and manure) without considering water evaporation and degeneration of organic $\mathrm{dm}$. In the winter period until April the measured $\mathrm{dm}$ values seem to be at an equal or a lower level than the calculated curve, indicating that the evaporation was insufficient to increase the $\mathrm{dm}$ content during the winter period. From May to November 2013 measured dm content was much higher than average dm content in the added material showing a significant water evaporation from the compost during the summer months.

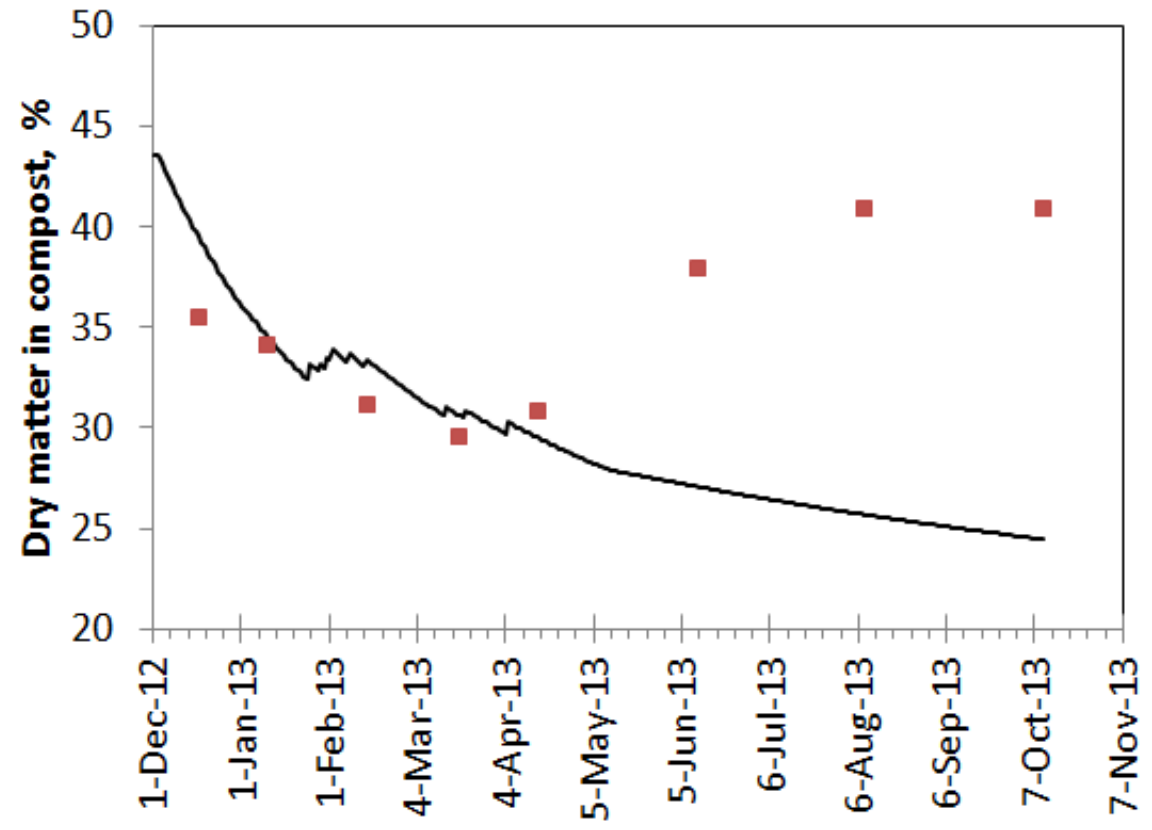

Figure 4. Dry matter content $(\mathrm{dm})$ in the compost during the investigated period. Red squares show measured values and the black curve shows average $\mathrm{dm} \%$ for estimated added bedding material without consideration to evaporation and degeneration of organic solids.

Average outdoor temperature during the winter period was around $0{ }^{\circ} \mathrm{C}$ and the indoor temperature was typically $2{ }^{\circ} \mathrm{C}$ above outdoor temperature. Measured temperature in the compost pack (Figure 5) showed that the compost typically were $20-40{ }^{\circ} \mathrm{K}$ warmer than the air, indicating a significant heat release in compost caused by degenerations of organic $\mathrm{dm}$ in the compost. This heat generation undoubtedly contributed to water evaporation, but because of the simultaneous degeneration of organic solids it was insufficient to increase the dm content. 


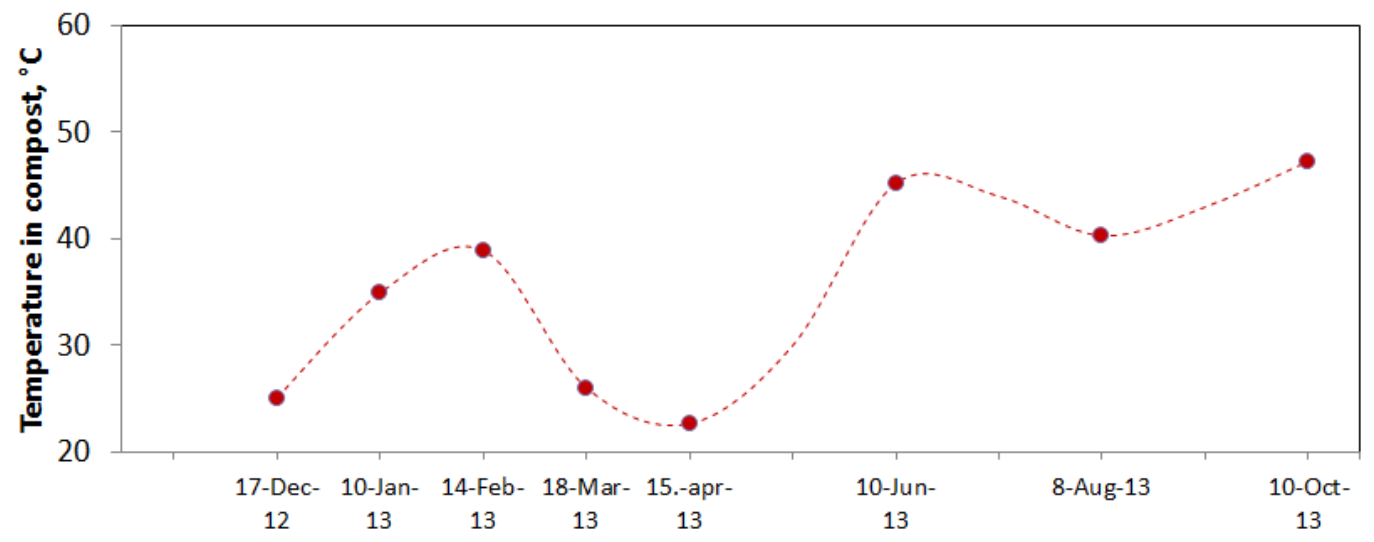

Figure 5. Compost temperature during the investigated period.

The finding that the water evaporation was insufficient to increase $\mathrm{dm}$ content during the winter period is of great relevance in relation to estimate the need for bedding material to ensure appropriate $\mathrm{dm}$ content in the bedding (40 - $60 \%$ according to Black and Bewley (2013)). Figure 6 shows calculated expected yearly requirement for bedding material to ensure either 40 or $50 \% \mathrm{dm}$ in the CBP. The calculation is based on equation 1 and the following assumptions;

- For a five month winter period the water evaporation is insufficient to increase the $\mathrm{dm}$ content.

- During the winter period the addition of manure in the compost is $4.9 \mathrm{t}(12 \% \mathrm{dm}) \mathrm{cow}^{-1}$

- No bedding material is required during a 7 month summer period.

- Dm content in bedding material is between 50 and 95\%.

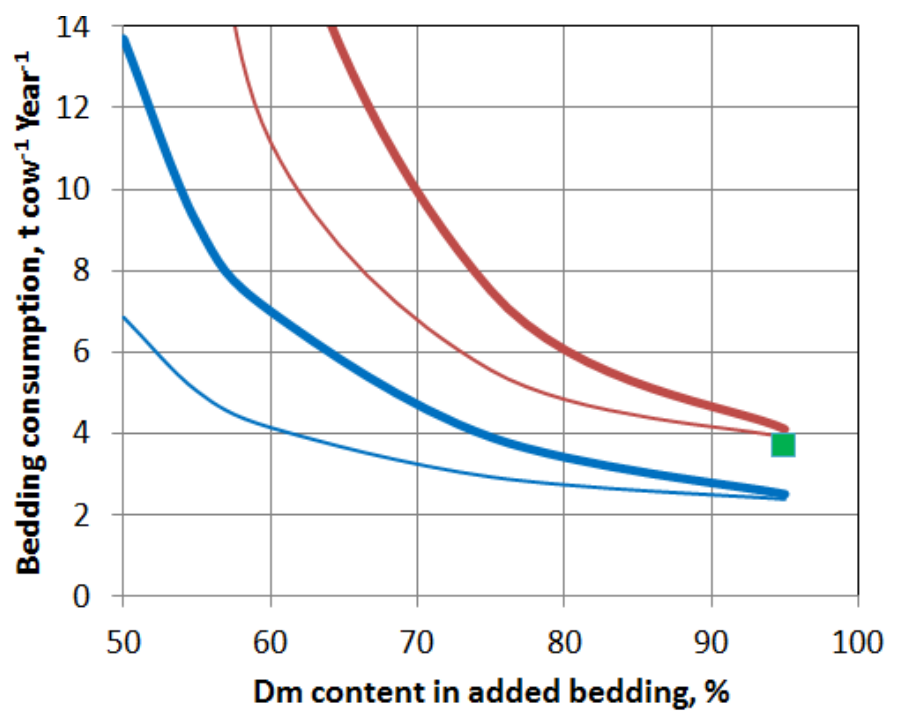

-Total mass consumption at $50 \% \mathrm{dm}$ in CBP

- Dm consumption at $50 \% \mathrm{dm}$ in CBP

-Total mass consumption at $40 \% \mathrm{dm}$ in CBP

- Dm consumption at $40 \% \mathrm{dm}$ in CBP

15 Kentucky CBP barns (Black et al. , 2013)

Figure 6. Calculated required bedding material to maintain either 40 or $50 \% \mathrm{dm}$ in CBP. The green bullet shows average bedding material consumption at 15 Kentucky barns that used kiln-dried shavings or sawdust as bedding material.

Figure 6 illustrates that a high dm content in the added bedding materials is essential to reduce the material consumption, and that it requires a significant increase in added bedding material to elevate the dm content in the CBP from 40 to $50 \%$.

The green bullet in the graph shows the average use of bedding material in 15 Kentucky CBP barns that all used kiln-dried shavings or sawdust as bedding material (Black et al., 2013). The authors informed that the daily consumption were $0.05 \mathrm{~m}^{3} \mathrm{cow}^{-1}$. This value was converted to the unit used in the graph by assuming a material density of $200 \mathrm{~kg} \mathrm{~m}^{-3}$ and a dm content of $95 \%$, and it indicates that the curves in graph may be consistent with the Kentucky experience.

The data collected in this study was not sufficient to document the effect of the installed under floor aeration 
system. But it is assessed that this system has contributed significantly to the increase in dm content (visible in Figure 4) during the early summer period and to that it was possible to operate the barn in a 193 days summer period without adding bedding material. In contrast to our findings Black et al. (2013) mention that all the barns in the Kentucky investigation added new shavings every $18.2 \mathrm{~d}(\mathrm{n}=39)$, ranging from every other day to every $45 \mathrm{~d}$, during the summer period, which support the assessment that the under floor aeration system enhanced the water evaporation in our study.

Measured at 15 locations in the bedding and repeated at 6 different days during the investigated period the ammonia emission were determined to $0.15( \pm 0.17) \mathrm{kg} \mathrm{N}_{\text {year }} \mathrm{m}^{-2}$. The emission from the solid floor feeding place was measured at nine locations on three different days and determined to $0.48( \pm 0.37) \mathrm{kg} \mathrm{N}_{\text {year }} \mathrm{m}^{-1}$.

For $10 \mathrm{~m}^{2}$ of compost area per cow and $3.5 \mathrm{~m}^{2}$ of solid floor feeding place per cow the total ammonia emission was calculated to $3.2 \mathrm{~kg} \mathrm{~N}_{\text {year }}{ }^{-1} \mathrm{cow}^{-1}$, see figure 7. A comparable free stall barn with a solid floor alleys of $5.1 \mathrm{~m}^{2} \mathrm{cow}^{-1}$, and using the mentioned emission of $0.48 \mathrm{~kg} \mathrm{~N}$ year ${ }^{-1} \mathrm{~m}^{-2}$, will cause an ammonia emission of 2.5 $\mathrm{kg} \mathrm{N}$ year $^{-1}$ cow $^{-1}$ (assuming no emission form the cubicles). This indicates that the emission from the compost bedded pack barn is approximately $30 \%$ higher than from a comparable free stall barn, and this is due to the large surface area per cow on the CBP.

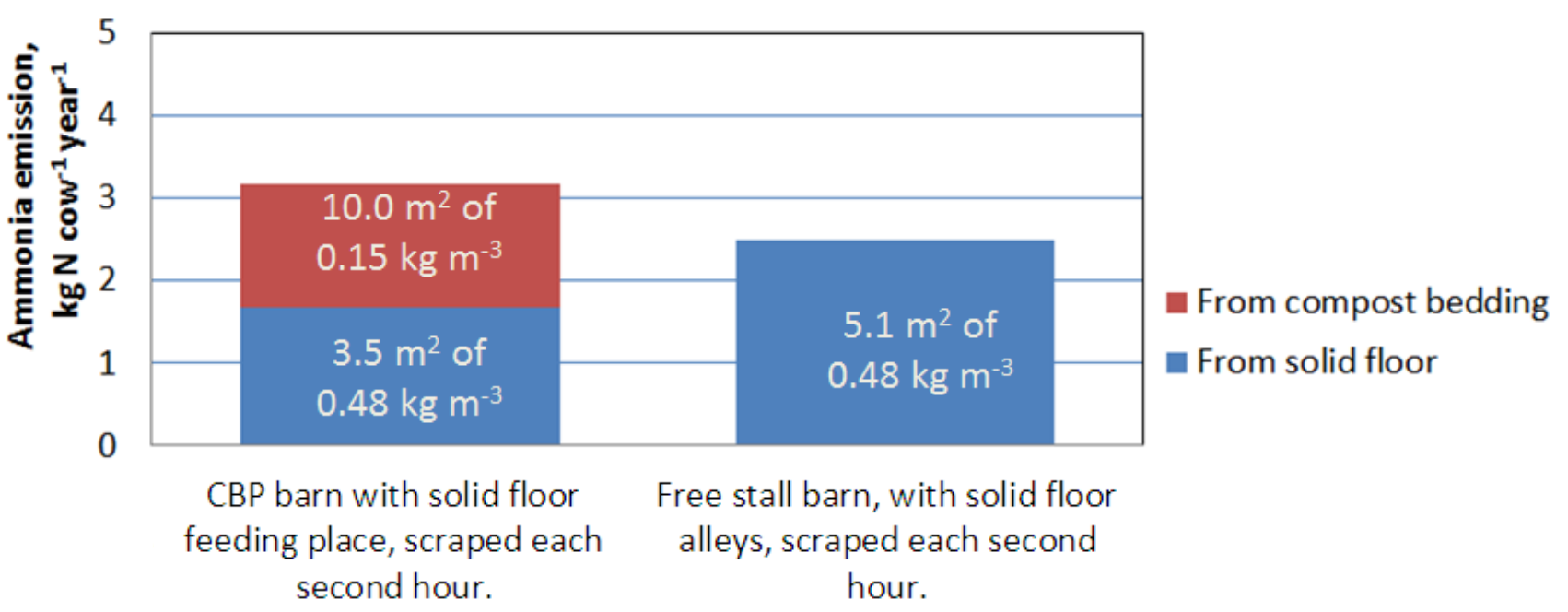

Figure 7. Estimated ammonia emission from a compost barn and from a free stall barn based on simple flux chamber measurements on CBP and on solid floor scraped each second hour.

Danish standard figures for animal manure (Poulsen 2012) include figures for expected ammonia emission from frequently used housing systems in Denmark. For a free stall dairy barn with solid floor alleys scraped each second hour the expected emission is $5.38 \mathrm{~kg} \mathrm{~N} \mathrm{cow}^{-1} \mathrm{year}^{-1}$, which is twice as much as found in our study. Possible explanations for this discrepancy are; that the measurements in this study were carried out at relative low out door temperatures, differences between different barns and uncertainty using both measure methods.

Figure 8 illustrates the expected ammonia emission from three frequently used free stall housing system mentioned in the Danish standard figures for animal manure (Poulsen 2012). The red bar illustrates the emission from a CBP barn assuming that the emission is $30 \%$ higher than from a free stall barn with solid floor alleys scraped each second hour. The graph indicates that the ammonia emissions observed from the Danish GBP barn lies within the variation that exists between the free stall housing that is frequently used in Denmark. 


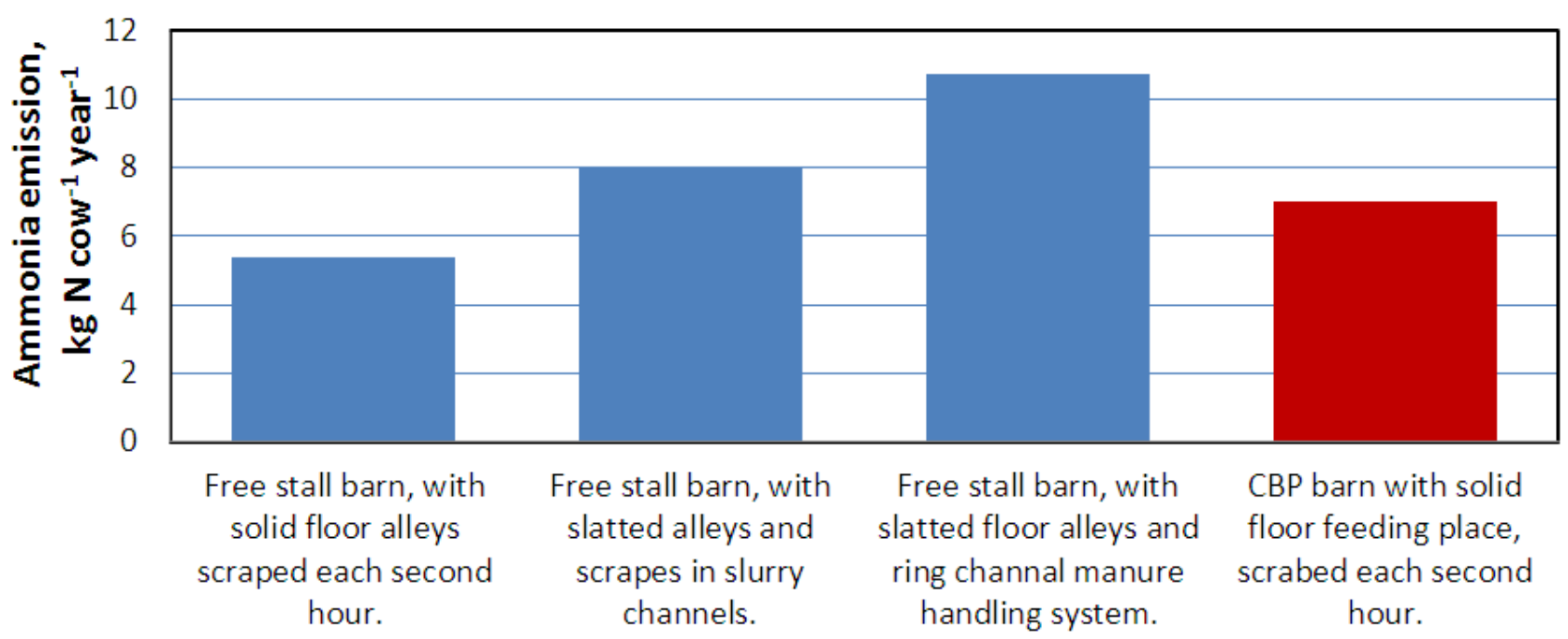

Figure 8. Expected ammonia emission from three frequently used free stall housing system mentioned in the Danish standard figures for animal manure and expected comparable emission from a CBP barn.

\section{Conclussions}

Water and ammonia evaporation was investigated in the first CBP dairy barn in Denmark during a 313 days period.

The water evaporation during the whole period amounted for $6.1 \mathrm{t} \mathrm{cow}^{-1}$ corresponding to $70 \%$ of moisture included in the added manure and bedding material. Because of the relatively large simultaneous degeneration of organic $\mathrm{dm}$ the water evaporation did not contribute to increased $\mathrm{dm}$ content in the CBP during the winter period. Conversely, in the summer period the water evaporation was so large that the $\mathrm{dm}$ content in the CBP increased significantly even though no bedding material were added during a 193 days period.

Simple flux chamber measurement showed that the ammonia emission per area units was approximately $70 \%$ lower from the CBP areas than from the solid floor feeding place scraped each second hour. But due to the large ammonia releasing area the emission from a CPB barn seems to be approximately $30 \%$ higher than from a free stall barn with solid floor alleys scraped each second hour. But the emission from the CPB barn is properly less than from different slatted floor free stall housing system also frequently used in Denmark.

\section{References}

Black, R. A., Taraba, J. L., Day,G. B., Damasceno , F. A., Bewley J. M. (2013) Compost bedded pack dairy barn management, performance, and producer satisfaction J. Dairy Sci. $96: 8060-8074$.

Black, R., J. Bewley (2013): Kentucky Compost-Bedded Pack Barn Project. University of Kentucky College of Agriculture.

Galama, P. (2011) Prospects for bedded pack barns for dairy cattle. Wageningen UR Livestock Research, Lelystad; 2011. p. 1-70.

Kousgaard,L. (2011). Measurement of ammonia emission from free stall barns bedded with manure fibers. Bachelor thesis(in Danish). Department of Large Animal Sciences, University of Copenhagen.

Poulsen, H. D. (2012). Standard figures for animal manure 2012 (in Danish).

http://anis.au.dk/forskning/sektioner/husdyrernaering-og-miljoe/normtal/ accessed 2013.11.22. 